\title{
EIF2B5 wt Allele
}

National Cancer Institute

\section{Source}

National Cancer Institute. EIF2B5 wt Allele. NCI Thesaurus. Code C53139.

Human EIF2B5 wild-type allele is located in the vicinity of 3q27.1 and is approximately 10 $\mathrm{kb}$ in length. This allele, which encodes translation initiation factor elF-2B subunit epsilon protein, is involved in the regulation of messenger RNA translation. Genetic mutations in the allele are linked to Cree leukoencephalopathy, leukoencephalopathy with vanishing white matter and ovarioleukodystrophy. 